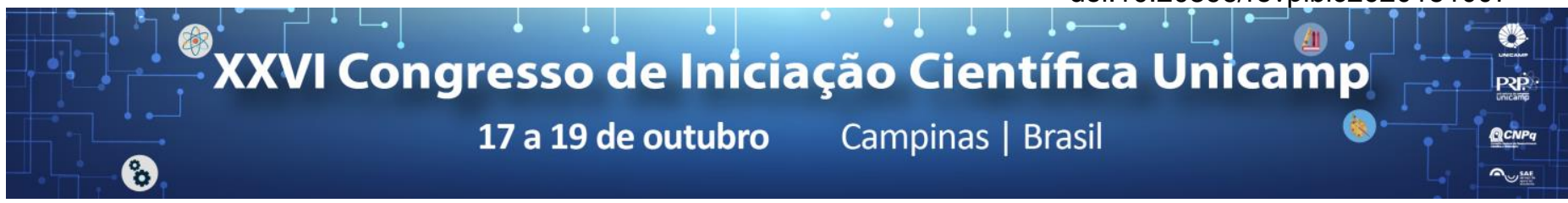

\title{
ANÁLISE PETROGRÁFICA DAS ROCHAS ECLOGÍTICAS DA REGIÃO DE IRAUÇUBA E JUÁ (CE)
}

\author{
Marina Guimarães Frias*, Ticiano José Saraiva dos Santos
}

\begin{abstract}
Resumo
Foram descritas 24 lâminas delgadas de rochas associadas à faixa eclogítica situada a sul da localidade de Irauçuba (CE). Foram identificados como principais litotipos: actinolita - hornblenda xisto, muscovita - hornblenda xisto, microclínio - muscovita - biotita - granada xisto, tremolita - forsterita - dolomita - calcita xisto, microclínio - actinolita hornblenda xisto, hornblenda - actinolita - biotita - granada - microclínio gnaisse, granada - biotita - actinolita xisto, diopsídio - hornblenda - granada anfibolito e diopsídio - calcita/dolomita xisto. O litotipo diopsídio - hornblenda granada anfibolito, com fácies metamórfica retroeclogito a anfibolito, onde ocorre grãos de granada com inclusões de hornblenda, mineral opaco, plagioclásio, rutilo e quartzo, este último, por vezes, desenvolvendo fraturas radiais.
\end{abstract}

\section{Palavras-chave:}

Eclogito, inclusões, quartzo

\section{Introdução}

O Arco magmático continental Santa Quitéria (AMCSQ) (Fetter et al., 2003), situado na porção centro norte do Estado do Ceará, entre os lineamentos Senador Pompeu e Transbrasiliano, constitui-se numa das mais importantes feições tectônicas da porção norte da Província Borborema. Bordejando o arco magmático a oeste tem-se a zona eclogítica de Forquilha, submetida a condições de ultra alta pressão atestada pela presença de coesita inclusa em granada (Santos et al., 2015). Na porção sul de Irauçuba e leste de Juá, ambas na porção oriental do AMCSQ, foram identificadas rochas metamáficas com espetaculares feições retro-eclogíticas, como simplectitos de clinopiroxênio - plagioclásio e granadas com incipiente textura atol. O objetivo da pesquisa foi analisar petrograficamente as rochas de alta pressão dessa região. Ênfase é dada à identificação de minerais inclusos em granadas, clinopiroxênio, coríndon e rutilo, que costumam conter minerais que possibilitam comprovar a passagem da rocha por zonas de alta pressão.

\section{Resultados e Discussão}

Para a realização desta pesquisa foi realizado levantamento de material bibliográfico acerca da geologia regional da área de estudo e descrição de lâminas delgadas em microscópio óptico. Estas lâminas são de diferentes litotipos e compreendem fácies metamórficas como granulito e eclogito retrometamorfizados para anfibolito.

A descrição de lâminas delgadas visou-se aprofundar os estudos nas de classificação diopsídio -hornblenda granada anfibolito, pois nestas ocorrem texturas poiquiloblásticas em granada, com inclusões de hornblenda, opacos, rutilo e quartzo desenvolvendo fraturas radiais na granada (Figura 1 ).

Algumas outras texturas de rochas encontradas nas lâminas foram simplectitos de diopsídio e plagioclásio, granadas com coronas de quartzo, plagioclásio e hornblenda, granadas com bordas de reação com hornblenda e quartzo e por fim, quartzo ribbon.


Figura 1. A) Grãos de quartzo com fraturas radiais inclusos em granada, em luz natural. B) Grãos de quartzo com fraturas radiais inclusos em granada, em luz polarizada.

\section{Conclusões}

Com base nos dados coletados, como: i) fácies metamórficas (retroeclogito a anfibolito); ii) associação mineral (com quartzo, - hornblenda, - granada; hornblenda, - plagioclásio; e hornblenda, - granada); iii) grau metamórfico (intermediário); iv) textura (poiquiloblástica, ocasionalmente com quartzos com fraturas radiais, simplectito, borda de reação, coronítica e quartzo ribbon) e; v) estrutura (xistosa) das rochas é possível concluir que o litotipo diopsídio - hornblenda granada anfibolito apresenta indícios de rocha de alta pressão.

\section{Ao CNPq pelo auxílio financeiro.}

\section{Agradecimentos}

\footnotetext{
${ }^{1}$ Fetter,A.H.; Santos, T.J.S.; Van Schmus, W.R.; Hackspacher,P.C; Brito Neves, B.B.; Arthaud, M.H., Nogueira Neto, J.A.; Wernick, E.- 2003 Evidence for Neoproterozoic Continental Arc Magmatism in the Santa Quiteria Batholith of Ceará State, NW Borborema Province, NE Brazil: Implications for the Assembly of West Gondwana. Gondwana Research, V. 6, No. 2, pp. 265-273.

2 Santos, T.J.S, Amaral, W.S.; Ancelmi, M.F.; Pitarello, M.Z.; Fuck, R.A.; Dantas, E.L. 2014. U-Pb age of the coesite-bearing eclogite from NW Borborema Province, NE Brazil: Implications for western Gondwana assembly. GondwanaResearch, doi:10.1016/j.gr.2014.09.013
} 